\title{
Tematyka dziecięco-młodzieżowa w badaniach naukowych i praktyce dydaktycznej Katedry Dydaktyki Języka i Literatury Polskiej
}

\author{
Children and teenager themes \\ in research and teaching practice of \\ Chair of Linguistic Didactics and Polish Literature
}

\begin{abstract}
Summary: The sketch characterizes the research areas of the staff of the Chair of Linguistic Didactics and Polish Literature, and especially the one devoted to literature for children and teenagers. The author of the article presents the beginnings and development of reflection on writing for a young reader, which, thanks to the involvement of Mieczysława Mitera-Dobrowolska, Zofia Adamczykowa and other employees, has become the foundation of studies on "other" literature, and thus the hallmark of Katowice's teaching of Polish literature and language among other Polish universities.
\end{abstract}

Keywords: literature for children and teenagers, Mieczysława Mitera-Dobrowolska, Zofia Adamczykowa, Chair of Linguistic Didactics and Polish Literature

W ciągu sześćdziesięciu lat istnienia Katedry Dydaktyki Języka i Literatury Polskiej niezmiennie w orbicie jej zainteresowań znajdowały się dziecko, dzieciństwo oraz młodość traktowane jako okresy najbardziej ważące w życiu człowieka. Wskazane zagadnienia wiązały się ze szkolnymi i z wychowawczymi badaniami prowadzonymi przez pracowników.

Wszystko zaczęło się od zakładu założonego w 1958 roku w Wyższej Szkole Pedagogicznej, który rok później został przekształcony w Katedrę Metodyki Literatury i Języka Polskiego. Jej twórczyni Mieczysława Mitera-Dobrowolska, choć żywo zainteresowana badaniami nad dzieciństwem, zajmowała się rów- 
nież dziejami oświaty oraz dydaktyką nauczania literatury i osiągnęła w tym zakresie pozycję wybitną. Zawsze jednak na obrzeżach jej głównych zainteresowań pojawiało się dziecko, czy to jako odbiorca, czy podmiot procesów edukacyjnych, czy w końcu jako bohater literacki. Wspomniana problematyka była również obecna w tematach prac magisterskich i doktorskich pisanych pod opieką naukową Mieczysławy Mitery-Dobrowolskiej.

Choć nie dysponujemy pełnym wykazem tematów rozpraw doktorskich (a tym bardziej magisterskich) zrealizowanych pod jej kierunkiem, to w kwestii dwóch z nich mamy całkowitą pewność. Otóż Zofia Szmytrowska, po mężu Adamczykowa, w 1972 roku obroniła dysertację doktorską na temat Marii Dąbrowskiej jako autorki książek dla dzieci i młodzieży ${ }^{1}$, a Zofia Świątyńska, po mężu Polakowska - doktorat poświęcony Teresie Jadwidze Papi, pisarce z przełomu XIX i XX wieku, której powieści były adresowane głównie do dziewcząt. Podobnie było z tematami prac magisterskich. Doktor Barbara Pytlos wspomina:

Pod kierunkiem Pani Profesor pisałam prace magisterska na temat wartości wychowawczych sztuki wedtug Hanny Januszewskiej „Pyza na polskich drózkach" (wyd. w 1956 roku2). Sztukę grano w katowickim Teatrze Lalek ,Ateneum" w latach 1966-1967. W owym czasie byłam prawie na każdym spektaklu tego teatru wystawianym $w$ Katowicach i na przedstawieniach wyjazdowych. Obserwowałam niezwykta reakcje dzieci, które wędrując z Pyza po polskich dróżkach, w lot wydobywaty z przedstawienia wartości poznawcze. Śledziły przygody bohaterki z otwartymi buziami. Temat pracy magisterskiej wynikat z moich ówczesnych zainteresowań. Należałam bowiem do Naukowego Koła Polonistów, w którym sprawnie działała sekcja teatrów lalkowych. O działalności teatrów lalkowych i ich znaczeniu kulturotwórczym w życiu dziecka (bielskiej Banialuki czy będzińskiego teatru prowadzonego przez Jana Dormana) rozmawiatyśmy $z$ Pania Profesor wiele razy. Rozmowy te sprawity, że Profesor poprosiła mnie, abym podzielita sie uwagami na ten temat ze studentami pierwszego roku polonistyki w latach 1966-1967. Wtedy bytam jeszcze studentka piatego roku. Ponownie ze studentami spotkatam się w następnym roku akademickim, już po obronie pracy magisterskiej ${ }^{3}$.

Ilekroć Mieczysława Mitera-Dobrowolska zauważyła u studenta pasję, zdolność samodzielnego badania problemu czy wychodzenie poza obowiązki seminaryjne, tylekroć dawała swobodę poznawczą. Tak też było z tematami „,zie-

${ }^{1}$ Praca ukazała się drukiem w 1979 roku. Zob. Z. Szmytrowska-Adamczykowa: Maria Dąbrowska. Pisarstwo dla dzieci. Katowice 1979.

${ }^{2} P y z a \ldots$ została napisana przed wojną, a po wojnie ukazała się z ingerencjami cenzury.

${ }^{3}$ Relacja znajduje się w posiadaniu autorki opracowania. 
cięcymi”. Zresztą sama była autorką wspomnieniowego artykułu o Czesławie Niemyskiej-Rączaszkowej, autorce wartościowych i interesująco napisanych powieści historycznych dla młodzieży, bliskiej znajomej z początków pracy w świeżo przywróconym Polsce szkolnictwie na Śląsku. Natomiast w większym opracowaniu, jakim była Historia wychowania pod redakcją Łukasza Kurdybachy (1968), pisząc o wychowaniu dziewcząt, szerzej omawiała twórczość Klementyny z Tańskich Hoffmanowej oraz charakteryzowała ówczesną literaturę dla dziewcząt, podkreślając jej rolę wychowawczą.

I o jeszcze jednym fakcie należy wspomnieć. Współpracując przy książce o dzieciństwie i młodości w cieniu swastyki, zatytułowanej Ślask chciał być polski. Wspomnienia młodzieży ślaskiej z lat okupacji hitlerowskiej 1939$1945^{4}$, pisząca te słowa mogła obserwować, jak twórczyni Katedry na długo wyprzedzała modne obecnie badania nad postpamięcią, wtedy jeszcze pamięcią „porażonej” młodości. Słuchałam wówczas opowieści o uczennicach Mieczysławy Mitery-Dobrowolskiej, wszak zawsze była żywo zainteresowana ich losem i wzruszająco zatroskana o ich pamięć. Gdy w 1983 roku wznosiliśmy pomnik harcerek i harcerzy na katowickim Rynku, Pani Docent upomniała się o upamiętnienie swej uczennicy Olgi Kamińskiej-Prokopowej. Ciesząca się tytułem „najpiękniejszej katowickiej harcerki”, została ścięta na gilotynie 9 marca 1943 roku o godzinie 19.06 w więzieniu Plötzensee. Była niezwykłą, bohaterską dziewczyną, która w dawnej Jugosławii współpracowała z konspiracyjną organizacją polsko-jugosłowiańską zajmującą się przerzutami zbiegów z krajów okupowanych, zwłaszcza z obozów jenieckich. Dziewiętnastoletnia Olga, mimo że spodziewała się dziecka, pilotowała przerzuty do Turcji. Aresztowano ją jesienią 1941 roku w Pirocie na granicy bułgarsko-tureckiej podczas przeprowadzania dwóch Anglików zbiegłych z Fortu VIII w Poznaniu: majora Littledale'a i porucznika Sinclaira. Pani Docent opowiadała o Oldze swym studentom, seminarzystom, a potem skutecznie interweniowała w Komitecie Budowy Pomnika, aby godnie upamiętnić zamordowaną.

Nic więc dziwnego, że w programach dydaktyki proponowanych przez Katedrę zawsze figurowały wykłady i seminaria z zakresu literatury dla dzieci i młodzieży. Wykłady prowadziły różne osoby, często ich realizację zlecano pracownikom spoza Katedry, np. takie wykłady prowadził Profesor Zbigniew Jerzy Nowak, czasem sama Docent Mieczysława Mitera-Dobrowolska, a potem po uzyskaniu doktoratu — jej wychowanki: Zofia Świątyńska-Polakowska i Zofia Szmytrowska-Adamczykowa, a później także Maria Zając, Bernadeta Niesporek-Szamburska, natomiast z młodszych pracownic Katedry - Małgorzata Wójcik-Dudek. Przedmiot nazywano wprawdzie żartobliwe „krasno-

${ }^{4}$ Śląsk chciat być polski. Wspomnienia młodzieży ślaskiej z lat okupacji hitlerowskiej 19391945. Wybór i oprac. M. Mitera-Dobrowolska; współpr. K. Heska-Kwaśniewicz. Katowice 1984. 
ludkami”, ale przez studentów był niezwykle lubiany i budził duże zainteresowanie.

Konieczna jest dygresja na temat miejsca tego przedmiotu w dydaktyce uniwersyteckiej. Bywał on bowiem realizowany na pedagogice, nauczaniu wczesnoszkolnym i wychowaniu przedszkolnym, bibliotekoznawstwie czy polonistyce. Wszędzie traktowano go trochę z przymrużeniem oka i zlecano osobom, którym akurat brakowało godzin do pensum. W Katedrze miał jednak inny status. Był przedmiotem traktowanym poważnie, profesjonalnie i z niezwykłym zaangażowaniem prowadzących zarówno wykłady, ćwiczenia, jak i seminaria magisterskie. Świadomość, że dobre książki czytane w dzieciństwie kształtują poczucie humoru i gust estetyczny, naturalnie wprowadzają w świat wartości oraz pobudzają wyobraźnię, okazała się nie do przecenienia dla przyszłych nauczycieli. Takie było przesłanie samej Mieczysławy Mitery-Dobrowolskiej.

Kontynuację tej idei Katedra zawdzięcza Zofii Szmytrowskiej-Adamczykowej, która wprowadziła katowickie „krasnoludki” do ogólnopolskiego kręgu badaczy. Uczestniczyła w Biennale Sztuki dla Dziecka od 1973 roku, zbliżyła się do środowiska warszawskiego (między innymi do Joanny Papuzińskiej), gdańskiego (Gertrudy Skotnickiej), wrocławskiego (Ryszarda Waksmunda) oraz nawiązała kontakty z badaczami skupionymi wokół Profesor Krystyny Kuliczkowskiej. Wszystkie działania cementowały środowisko oraz budowały podstawy systematycznych i dobrze zorganizowanych badań nad problemami literatury dla niedorosłych czytelników. Prowadzone przez nią seminaria magisterskie, jak w dalszej perspektywie miało się okazać, były bardzo istotne dla przyszłości badań nad literaturą dla młodych i najmłodszych odbiorców. Seminarzystką Zofii Adamczykowej była przecież Małgorzata Wójcik-Dudek.

Nieco później zaczęła się w Katedrze rozwijać refleksja badawcza nachylona w stronę języka dziecka - fascynującej dziedziny, ulokowanej na granicy psychologii, językoznawstwa i literatury, wymagającej od badacza oprócz wiedzy, dużej wrażliwości emocjonalnej. $Z$ tego typu badaniami związana jest Profesor Bernadeta Niesporek-Szamburska. Nurt ten rozpoczęty studiami nad językowym obrazem świata związanym ze świętym Mikołajem, a więc zjawiskiem zarówno religijnym, jak i kulturowym, doprowadził uczoną do badań nad listami dzieci do świętego Mikołaja, a zatem pewnego rodzaju samorodnej twórczości dziecięcej. Skutkowało to odkryciem niebanalnego obszaru badawczego, ale też fascynacją językoznawczyni, szukającej wiedzy nie tylko o mowie dziecka, ale też o jego swobodnej, jeszcze nieograniczonej wyobraźni, emocjach czy aksjologii. Studia nad językiem dziecka stały się zarówno początkiem ważnej przygody naukowej, jak i zaowocowały poszerzeniem obszarów badawczych Katedry, która już wówczas promieniowała na inne jednostki w kraju. Badania Profesor Niesporek-Szamburskiej przyczyniły się nie tylko do zainteresowania utworami dla dzieci, twórczością dziecięcą i kształtowaniem świadomości językowej dzieci, ale również rolą, jaką odgrywają dorośli 
w procesie inspirowania lub tłumienia twórczej inwencji dziecka, zresztą nie tylko literackiej.

Tego typu zakres tematyczny doskonale harmonizował z badaniami i publikacjami Doktor Zofii Adamczykowej. Pod jej opieką rozwinęła swe skrzydła Małgorzata Wójcik-Dudek, znakomita badaczka „literatury czwartej”, ze znawstwem łącząca zainteresowanie twórczością dla dzieci z problematyką Zagłady (w znakomitej rozprawie habilitacyjnej Praktyki postpamięci $w$ polskiej literaturze XXI wieku dla dzieci i mtodzieży ${ }^{5}$ ). Problematykę literatury dziecięcej mniej lub bardziej okazjonalnie podejmują także inni pracownicy Katedry. Na przykład Profesor Ewa Jaskółowa, choć sama takich badań nie prowadziła, swojej doktorantce Karolinie Jędrych (obecnie Starnawskiej) podsunęła temat o twórczości Marii Krüger ${ }^{6}$. W swej pracy naukowej literaturę i sztukę dla dzieci z powodzeniem łączyła Doktor habilitowana Ewa Ogłoza, której książka Wokót opowieści Hansa Christiana Andersena. O radości czytania ${ }^{7}$ stanowiła bardzo odkrywcze odczytanie baśni słynnego Duńczyka. Także Profesor Helena Synowiec, wracając do ulubionych lektur dzieciństwa, napisała szkic o dydaktyczno-językowych inspiracjach w Cudaczku-Wyśmiewaczku Julii Duszyńskiej.

Widać więc, że obszar badawczy dotyczący literatury dla dzieci i młodzieży pozostawał cały czas obecny i bliski zespołowi Katedry, mimo że „krasnoludkowy” przedmiot czasem trzeba było ukrywać pod innymi „szyldami”. I choć Docent Mieczysława Mitera-Dobrowolska przeszła na emeryturę, a w 1992 roku zmarła (najwyższy czas w prowadzić hasło „Mieczysława Mitera-Dobrowolska” do Wikipedii!), to jednak zarówno jej następca Profesor Edward Polański, a potem Profesor Anna Opacka, Profesor Helena Synowiec, jak i Profesor Ewa Jaskółowa cenili w dydaktyce obecność literatury dla dzieci i młodzieży. Dziecięca radość zabawy słowem bywa wszak bliska nie tylko poetom, ale także niektórym uczonym, szczególnie tym, dla których motorem działania nie jest konieczność awansu, lecz radość tworzenia. Napisał kiedyś Julian Przyboś:

[...] że dzieciństwo waży w życiu poety więcej niż ta sama ilość lat w wieku dojrzałym - przyznają wszyscy, nie tylko poeci, ale i ci, którzy z biegiem lat, późno rozumieją swój los ${ }^{8}$.

Otóż badacze, a zwłaszcza badaczki współczesnej literatury, ten los na ogół pojmują wcześniej. Można więc pozwolić sobie na metaforę, że ziarno zasiane

${ }^{5}$ M. Wójcik-Dudek: Praktyki postpamięci w polskiej literaturze XXI wieku dla dzieci i młodzieży. Katowice 2016.

${ }^{6}$ Zob. K. Jędrych: Portret dziewczynki, dziewczyny i kobiety w powieściach Marii Krüger. Katowice 2017. 2014.

${ }^{7}$ E. Ogłoza: Wokół opowieści Hansa Christiana Andersena. O radości czytania. Katowice

8 J. Przyboś: Zapiski bez daty. Warszawa 1970, s. 120. 
przez Mieczysławę Miterę-Dobrowolską padło na podatny grunt i wzrastało, owocując mimo zmiennych kolei losu. W XXI wieku rozpoczął się nowy okres badań, co oznaczało wychodzenie poza obszar stricte literaturoznawczy w stronę dziecka poznającego język. Profesor Bernadeta Niesporek-Szamburska, prekursorka tych badań, zrobiła habilitację w maju 2004 roku i poruszyła całą Radę Wydziału odkrywczością analiz oraz świeżością spojrzenia na badane przez siebie zagadnienie. Profesorska książka Niesporek-Szamburskiej zatytułowana Stereotyp ,czarownicy” i jego modyfikowanie. Na przykładzie tekstów dla dzieci i wypowiedzi dziecięcych (2013) znów odkrywała kolejny obszar poszerzający zakres badań nad bogactwem znaczeniowym, kulturowym i językowym pisarstwa dla dzieci, nobilitując zarazem nową tematykę badawczą. Autorka zajęła się wierszami współczesnych poetów (Danuta Wawiłow, Małgorzata Strzałkowska, Agnieszka Frączek, Łukasz Dębski) zainteresowanych materią języka. Obecnie te problemy podejmują doktorantki Pani Profesor piszące na temat języka dzieci, które korzystając z literatury dla dzieci, „budują” językowe obrazy wyobrażeń mitycznych rodem z baśni oraz bajeczek.

Z seminarium Doktor Zofii Szmytrowskiej-Adamczykowej „wyszła” Małgorzata Wójcik-Dudek pisząca w 2000 roku dysertację o podwójnym odbiorcy poezji Józefa Ratajczaka. Badaczka, dziś już doktor habilitowana, profesor Uniwersytetu Śląskiego, w 2004 roku została przyjęta do Katedry na miejsce Zofii Adamczykowej, odchodzącej wtedy na emeryturę. Wprawdzie doktorat pisała z innej tematyki (2004), ale jej podstawowy dorobek dotyczy świata literatury dziecięco-młodzieżowej, czy może na nowo go odkrywa. W 2016 roku badaczka wydała wspomnianą już cenną książkę habilitacyjną o Holokauście i postpamięci w literaturze dla dzieci.

Z fascynacji literaturą dla dzieci i młodzieży zrodził się pomysł ogólnopolskich konferencji realizowanych głównie przez Małgorzatę Wójcik-Dudek i Bernadetę Niesporek-Szamburską. Spotkania cechowały wspaniała atmosfera, wysoki poziom referatów oraz odkrywcze dyskusje. Dodajmy, że na tych sesjach spotykali się badacze wszystkich pokoleń, od najstarszych do najmłodszych, z prawie wszystkich ośrodków badawczych w Polsce, natomiast plonem obrad były opracowania monograficzne zawsze wysoko oceniane w środowisku naukowym, niecierpliwie czekającym na kolejną konferencję. Dzięki temu Katowice znów wybiły się na wiodący ośrodek badań nad najpierwszą literaturą człowieczą. Od 2009 roku co dwa lata spotykano się na inspirujących sesjach: Dziecko - język — tekst (2009), Nowe opisanie świata. Literatura dla dzieci i młodzieży w kręgach oddziaływań (2012), Wyczytać świat - międzykulturowość w literaturze dla dzieci i młodzieży (2013), (Przed)szkolne spotkania z lektura (2015), (Od)pamiętywanie - gry z przeszłościa w literaturze dla dzieci i młodzieży (2017), Doświadczanie lektury. Zmysty i literatura osobna (2018).

Dodać też trzeba, że pracownicy Katedry bardzo chętnie współpracowali z innymi zespołami badawczymi podejmującymi podobne inicjatywy. Tak 
było ze skryptem z literatury dla dzieci i młodzieży, którego projekt powstał w Instytucie Bibliotekoznawstwa, a który Panie Profesor Bernadeta Niesporek-Szamburska, Małgorzata Wójcik-Dudek, Karolina Jędrych, a w drugim tomie również Krystyna Koziołek wsparły swymi znakomitymi piórami. Także w „Guliwerze. Czasopiśmie o Książce dla Dziecka” często można było napotkać ich teksty.

\section{$* * *$}

Zaczęło się więc przed sześćdziesięcioma laty od ziarna rzuconego na żyzną glebę przez Doktor Mieczysławę Miterę-Dobrowolską. Wyrosło z niego drzewo mocne, bujnie rozgałęzione o dwu mocnych pniach. A uczennica niezapomnianej „Mieci” Doktor Zofia Adamczykowa dobrze dbała o wzrost tego drzewa i wychowała własną , gałązkę”, czyli dr hab. Małgorzatę Wójcik-Dudek, w linii prostej „wnuczkę" Mitery-Dobrowolskiej. To drzewo więc kwitnie i owocuje, a zarazem wydaje piękny, dojrzały plon w postaci elektronicznego czasopisma „Paidia i Literatura”, a więc semper sint in flores.

\section{Bibliografia}

Jędrych K.: Portret dziewczynki, dziewczyny i kobiety w powieściach Marii Krüger. Katowice 2017.

Ogłoza E.: Wokół opowieści Hansa Christiana Andersena. O radości czytania. Katowice 2014. Przyboś J.: Zapiski bez daty. Warszawa 1970.

Szmytrowska-Adamczykowa Z.: Maria Dabrowska. Pisarstwo dla dzieci. Katowice 1979.

Ślask chciał być polski. Wspomnienia młodzieży śląskiej z lat okupacji hitlerowskiej 1939-1945.

Wybór i oprac. M. Mitera-Dobrowolska; współpraca K. Heska-Kwaśniewicz. Katowice 1984.

Wójcik-Dudek M.: Praktyki postpamięci w polskiej literaturze XXI wieku dla dzieci i młodzieży. Katowice 2016.

\footnotetext{
${ }^{9}$ Pierwszy numer pisma ukazał się w postaci elektronicznej w 2019 roku.
} 